\title{
Job Stress, Emotional Labor, and Emotional Intelligence as Predictors of Turnover Intention: Evidence from Two Service Occupations
}

\author{
Bolanle Ogungbamila
}

Anthony G. Balogun

Adepeju Ogungbamila

Richard S. Oladele

Adekunle Ajasin University

Email: o_bolanle@yahoo.com, bolanle.ogungbamila@aaua.edu.ng

Doi:10.5901/mjss.2014.v5n6p351

\section{Abstract}

This study investigated the extent to which job stress, emotional labor, and emotional intelligence predict turnover intention among bank and health workers. Sample comprised 270 employees (bank = 149; health =121), whose ages averaged 33.04 $(S D=7.86)$. Results of the hierarchical multiple regression revealed that job stress did not predict turnover intention. However, emotional labor increased employees' turnover intention. Emotional intelligence led to a reduction in employees' level of turnover intention. Bank workers reported higher level of turnover intention than health workers. In order to reduce turnover intention among employees in service occupations, emotional demands placed on them should be reduced while their level of emotional intelligence should be enhanced.

Keywords: Turnover, emotions, stress, bank, health, Nigeria.

\section{Introduction}

The negative consequences of employees' turnover intention on the organization in terms of loss of valuable and skilled employees, increased costs of recruiting, selecting, and training of new workers, low competitive advantage, and disruption in workflow (Miller, 2010; Mustapha \& Mourad, 2007; Price 2001; Wagner, 2010) has made it one of the most studied topics in organizational psychology (Galletta, Portoghese \& Battistelli, 2011; Griffeth, Hom \& Gaertner, 2000; Oyetola, 2013). Most studies (e.g. AbdulRahman, Raza \& Ismail, 2008; Adeyemo \& Afolabi, 2007; Carmeli, 2003) on turnover intention identified organizational-based factors, attitudinal variables, and demographic factors as major factors influencing turnover intention. Less research attention has focused how job stress, emotional labor, and emotional intelligence connect with turnover intention especially among employees in the banking and health sectors in Nigeria, who may be the most affected by the dearth of qualified personnel (Balogun \& Olowodunoye, 2012; Ojedokun, 2008; Owolabi, 2012). This study aimed to fill this vacuum.

\section{Literature Review and Hypotheses}

Job stress, which is conceptualized as the mental, emotional, and physical drain brought about by the perceived incongruence between job demands and employees' capabilities and resources (Akinboye \& Adeyemo, 2002), may be an important factor in turnover intention(Adebayo \& Ogunsina, 2011). This is because high level of job stress has been linked to increased headache, cancer, heart disease, depression, anxiety, and emotional distress (Cartwright \& Cooper, 1997) decreased well-being, increased psychological distress, violence, and the desire to quit the job (Oginni, Afolabi Erigbe, 2013; Pascal, 2011). Job stress may emanate from the work environment, especially service-oriented work environment (e.g. bank). For example, the Nigeria banking industry is characterized by long working hour, lack of shifting, low pay, work pressure, high job target, excessive workload, and pressure from customers were elements of job stress (Adejuwon \& Lawal, 2013; Ogungbamila, 2010), which can lead to physical and psychological disorders and turnover intention (Oginni, et al., 2013).

These stressors or job demands, according to the job demand-resources and job demands-control models, can 
lead to depletion of energy and lack of motivation, especially when they exceed the employees coping capability and may culminate in negative work outcomes such as job dissatisfaction and turnover intention (Adebayo \& Ogunsina, 2011; Bakker, Demerouti \& Schaufeli, 2003). Job demands may not automatically lead to negative outcomes. Job demands may result in job stress and burnout if the workers do not have adequate resources such as social support and job control (Bakker \& Demerouti, 2007). The person-environment fit theory (French \& Chaplan, 1970) posited that employees experience low level of job stress or strain when their skills, abilities, and personality match the demand and requirements of the job. Consequently, any form of disequilibrium between employees' skills and abilities and the job requirements may lead to job stress (Ogungbamila, 2013) and result in intention to quit and turnover behaviour (Ngo, Sharon, \& Raymond, 2005; Oginni, et al., 2013; Tuten \& Neidermeyer, 2004). It was, therefore, hypothesized that:

Hypothesis 1: Job stress positively predicts turnover intention.

Most service occupations (e.g. banking and health) require their employees to face client (customer or patient) with a smile and friendliness in order to meet the clients' need(s) at the expense of their own felt emotions (Ehigie, Oguntuase, Ibode \& Ehigie, 2012). Recent studies submitted that such organizationally expected emotions are closely related to emotional dissonance (incongruence between felt and displayed emotions) and emotional exhaustion (depletion of energies and coping resources due to constant exposure to high job demands), which culminate in occupational stress and burnout (Grandey, 2002; Morris \& Feldman, 1996; Ogungbamila, 2013; Weiss \& Cropanzano, 1996). Burnout or emotional exhaustion can result in job dissatisfaction and intention to quit (Bakker, Demerouti \& Schaufeli, 2003).

Available studies indicated that manipulation of one's emotions to suit the demands of one's organization may result to turnover intention. This act of regulating and managing emotions for a wage or salary is what Hochschild (1983) termed emotional labor. Emotional labor is a deliberate and conscious act of displaying, regulating or altering one's felt, original, or inner emotions for the purpose of complying with the interpersonal demands required for performing a job (Hochschild, 1983). It involves the manipulation of one's inner feelings or outward behaviour in order to display the appropriate emotion in compliance with organizational rules or occupational norms (Ehigie et al., 2012; Oluwole, 2008).

Emotional labor can be performed in three major ways: deep acting, surface acting, and genuine acting (Brotheridge \& Lee, 2003; Hochschild, 1983; Oluwole, 2008). Employees who exhibit deep acting change or modify felt emotion to suit job-required emotion whereas in surface acting, the employee only alter their displayed emotions without modifying felt emotions (e.g. when an angry bank or health worker fakes a smile to satisfy the customer's or patient's service requirement of the job). Unlike the other two acting mechanisms, genuine acting requires little or no efforts as the felt emotion is already in line with the required emotion. Chau, Dahling, Levy and Diefendorff (2009) reported that employees who were forced to engage in surface acting of emotional labor exhibited higher tendency to quit their job than those who engaged in deep acting. Based on this, it was hypothesized that:

Hypothesis 2: Emotional labor positively predicts turnover intention.

The connections of job stress and emotional labor to turnover intention may be affected by emotional intelligence (EI). El is the constellation of skills and abilities that enable an individual to understand, regulate, and manage emotion in self and others (Salovey \& Mayer, 1990). It involves the assimilation, expression, regulation, and management of emotional information for adaptive purposes (Goleman, 1995, 1998; Mayer, Salovey \& Caruso, 2000). Emotionally intelligent employees are assertive, optimistic, tolerant, flexible, and immune to stress because they are adept at putting themselves in a positive state of mind (Bar-On, 2005; Griffeth, 2000).

Recent studies on El and workplace outcomes indicated that El is related to job performance, emotional labor, job satisfaction, effective leadership, and productivity (Carmeli, 2003; Caruso, Mayer \& Salovey, 2001; Ehigie et al., 2012). El may also affect workers' intention to quit. For example, Adeyemo and Afolabi (2007) reported that emotionally intelligent workers experience low level of withdrawal cognition. Ajay (2009) reported that emotional intelligence predicted turnover intention. Specifically, El had a negative relationship with turnover intention (Falkenburg \& Schyns, 2007; Lee \& Liu, 2007; Wong \& Law, 2002). This may be because El affects intrapersonal well-being and interpersonal relations, which also affect workers' attitudes to their colleagues, their bosses and their job (Salami, 2008). Against this background, it was hypothesized that:

Hypothesis 3: Emotional intelligence negatively predicts turnover intention.

There is dearth of literature on inter-occupational comparison of turnover intention among employees in service occupations in Nigeria. However, it is expected that bank workers would form higher turnover intention than health workers. This is connected with the fact that the prevailing circumstance in the Nigeria banking sector has placed bank workers under extreme pressure (Ogungbamila, 2010) coupled with high job insecurity (Ojedokun, 2008). Consequently, it was hypothesized that:

Hypothesis 4: Bank workers exhibit higher turnover intention than health workers. 


\section{Methods}

\subsection{Design and Participants}

This was a cross-sectional survey. The participants were 270 workers (bank $=149$; health $=121$ ), sampled from 2 commercial banks and 4 hospitals in a large city in southwest, Nigeria. They comprised 146 males and 124 females, whose ages ranged between 25 and 65 years $(M=33.04$; $S D=7.86)$. They had spent an average of 5.2 years $(S D=$ 4.85) on the job. In terms of academic qualification, 22 (8.1\%) of the participants had up to School Certificate, 20 (7.4\%) had National Certificate in Education/ Ordinary National Diploma, 176 (65.2\%) had Higher National Diploma/ first degree, and $52(19.3 \%)$ had postgraduate degree. In the case of job level, 93 (34.4\%) of the participants were in the junior cadre, $52(19.3 \%)$ were in the intermediate cadre, 101 (37.4\%) were in the senior cadre, and $24(8.9 \%)$ were in the management cadre.

\subsection{Measures}

Job Stress was measured using Theorell's (1988) Job Stress Scale (JSS). It was a 17-item version of the modified 49item scale originally developed by Karasek (1979) to tap employees' perception of job demands, job control, and social support. Job demands (5 items), and job control (6 items) subscales were rated on a 4-point scale $(1=$ often; $4=$ never/almost never). Social support (6 items) was also rated on a 4-point scale ( 1 = strongly agree; $4=$ strongly disagree). Sample items included: "Do you have to work very fast?" (Job demands), "Do you have a choice in deciding HOW you do your work?" (Job control), "My co-worker supports me" (reverse scored) (social support). Theorell (1988) reported Cronbach's alpha coefficient of .79, .87, and .85 for the job demand, job control, and social support subscales, respectively. In this study, a Cronbach's alpha of .71 was obtained for the overall scale. High score on the scale implied high job stress and low score meant low job stress.

Emotional Labor was measured using a 19-item Hospitality Emotional Labor scale developed by Chu (2002). The scale was designed to measure surface and deep acting of emotional labor. Items were scored on a 5-point scale (always $=5$; never =1). Sample item include: "I have to cover my true feelings when dealing with customers or patients". Ehigie et al., (2012) reported a coefficient alpha value of .72 and .59 for deep acting and surface acting, respectively while a coefficient alpha value of .53 was obtained for overall scale. In this study, a Cronbach's alpha of .71 was obtained for the overall scale. The higher the score of an employee on the scale, the more he/she engaged in emotional labor.

Emotional intelligence was measured using a 30-item self-report Trait Meta-Mood Scale (TMMS) developed by Salovey, Mayer, Goleman, Turvey and Palfai (1995). TMMS measures the core areas of emotional intelligence: emotional attention (13 items), emotional clarity (11 items), and mood repair (6 items). Examples of items are: "Feelings give direction to life" (emotional attention), "I am usually very clear about my feelings" (emotional clarity), and "When I become upset I remind myself of all the pleasures in life" (mood repair). The scale was rated on a 5-point scale $(1=$ Strongly Disagree; 5 = Strongly Agree). Using a Nigerian sample, Ogungbamila (2011) obtained .76 Cronbach's alpha for the overall scale. In the present study, a Cronbach's alpha of .73 was obtained for the overall scale. Scores above the mean reflected high emotional intelligence and score below the mean indicated low emotional intelligence.

Turnover intention was measured using a 3-item scale developed by Mobley, Horner and Hollingsworth (1978). The scale measured employees' thought of quitting, the intention to search for another job elsewhere, and the intention to quit. The scale was scored on a on a 7-point scale $(1=$ strongly disagree; 7 = strongly agree). Sample item included: "I think a lot about leaving this organization". Balogun and Olowodunoye (2012) obtained a Cronbach's alpha of .71 for the scale among a Nigerian sample. In this study, a Cronbach's alpha of .73 was obtained for the scale. Scores above the mean indicated high turnover intention.

\subsection{Procedure}

Permission was obtained from the management of each of the banks and hospitals visited by the researchers before the administration of the questionnaires. The consent of the prospective participants was sought after a brief explanation of the purpose of the research'. This study adopted accidental sampling technique in the distribution of the questionnaire because the nature of the job in banks and hospitals may not permit a more rigorous sampling technique (Ogungbamila, 2013). Those who consented were given a copy of the questionnaire with the assurance of anonymity and confidentiality of responses. Three hundred questionnaires were administered, 277 were collected and 270 were found usable for the analysis, yielding a response rate of $92.3 \%$. 


\section{Results}

\subsection{Descriptive and correlations}

The results of the descriptive and Correlational analyses of the variables are presented Table 1.

Table 1: Mean, SD, and Correlations among the Study Variables

\begin{tabular}{|c|c|c|c|c|c|c|c|c|c|c|c|c|}
\hline Variables & $M$ & $S D$ & 1 & 2 & 3 & 4 & 5 & 6 & 7 & 8 & 9 & 10 \\
\hline 1. Age & 33.04 & 7.84 & - & $.38^{\star}$ & $.30 * \star$ & $.49 * \star$ & .79 & -.04 & $-.12^{\star}$ & $.13^{*}$ & .01 & -.02 \\
\hline 2. Gender & - & - & & - & .05 & .02 & $.51^{\star *}$ & -.04 & $.17^{*}$ & $-.18^{*}$ & -.04 & $.14^{\star \star}$ \\
\hline 3. Academic qualification & - & - & & & - & $.11^{\star *}$ & $.51^{\star *}$ & $.12^{*}$ & $-.20^{*}$ & $.75^{\star *}$ & $.12^{\star *}$ & $-.16^{*}$ \\
\hline 4. Job level & - & - & & & & - & -.08 & -.03 & -.15 & .03 & -.03 & $.43^{*}$ \\
\hline 5. Job tenure & 5.30 & 4.85 & & & & & - & -.04 & $-.65^{\star *}$ & .08 & -.04 & $.13^{*}$ \\
\hline 6. Occupation & - & - & & & & & & - & -.40 ** & .03 & -.06 & $.61^{\star \star}$ \\
\hline 7. Job stress & 48.25 & 10.11 & & & & & & & - & $.13^{*}$ & $-.86^{\star *}$ & .09 \\
\hline 8. Emotional labor & 59.02 & 9.58 & & & & & & & & - & $-.33^{\star *}$ & $.52^{\star \star}$ \\
\hline 9. Emotional intelligence & 87.47 & 14.23 & & & & & & & & & - & $-.48^{\star}$ \\
\hline 10.Turnover intention & 13.97 & 4.00 & & & & & & & & & & - \\
\hline
\end{tabular}

Note: ${ }^{*} p<.05 .{ }^{* \star} p<.01 . \mathrm{N}=270$. Occupation was coded health 0 ; bank 1. Gender was coded female 0 ; male 1. Academic qualification was coded up to School Certificate 1; National Certificate in Education/ Ordinary National Diploma 2; Higher National Diploma/ first degree 3; and postgraduate degree 4. Job level was coded junior cadre 1; intermediate cadre 2; senior cadre 3; and management cadre 4.

As shown in Table 1, type of occupation had a significant positive relationship with turnover intention $[r(268)=.61, p<$ .01]. This implied that bank workers tended to form higher turnover intention than health workers. Job stress had no significant relationship with turnover intention $[r(268)=.09, p>.05)$. A significant increase in emotional labor was related with high turnover intention $[r(268)=.52, p<.01]$. High emotional intelligence was significantly related with low turnover intention $[r(268)=-.48, p<.05]$.

\subsection{Test of Hypotheses}

Hypotheses 1 - 3 were tested using hierarchical multiple regression analysis. In step 1 of the analysis, the demographic variables were entered into the regression model. In step 2, the psychological variables (job stress, emotional labor, and emotional intelligence) were entered into the model. The results are presented on Table 2.

Table 2: Summary of Hierarchical Multiple Regression on Turnover Intention

\begin{tabular}{lcc}
\hline \multicolumn{1}{c}{ Predictors } & Step 1 & Step 2 \\
\hline Demographic variables & $\beta$ & $\beta$ \\
Age & $-.28^{*}$ & $-.17^{\star}$ \\
Gender & .09 & .09 \\
Academic qualification & .00 & .01 \\
Job level & $-.12^{*}$ & $-.13^{\star}$ \\
Job tenure & $-.48^{*}$ & $-.25^{\star *}$ \\
Psychological variables & & \\
Job Stress & & .03 \\
Emotional Labor & & $.45^{* *}$ \\
Emotional Intelligence & & $-.22^{\star *}$ \\
$R^{2}$ & .11 & .61 \\
$\Delta R^{2}$ & .11 & .37 \\
$F$ & $3.30^{* *}$ & $2.53^{* *}$ \\
$\Delta F$ & 3.30 & 1.72 \\
\hline
\end{tabular}

Note: ${ }^{*} p<.05 .{ }^{* \star} p<.01 . \mathrm{N}=270$. Gender was coded female 0 ; male 1. Academic qualification was coded up to School Certificate 1; National Certificate in Education/ Ordinary National Diploma 2; Higher National Diplomal first degree 3; and postgraduate degree 4. Job level was coded junior cadre 1; intermediate cadre 2; senior cadre 3; and management cadre 4. 
Table 2 shows that age, gender, marital status, academic qualification, job level, and job tenure jointly contributed to turnover intention $\left(R^{2}=.11, F(5,264)=3.30, p<.01\right)$. They accounted for $11 \%$ variance in turnover intention. In the case of independent contribution, only age $(\beta=-.28, p<.05)$, job level $(\beta=-.12, p<.05)$, and job tenure $(\beta=-.48 ; p<$ .05 ) had significant independent effects on turnover intention. The implication was that as employees' age increased the tendency to quit the job decreased. The intention to quit the job reduced as employees' job level and job tenure increased.

To test the independent effects of the psychological variables on turnover intention, the variables were introduced in step 2 of the analysis. Results indicated that job stress did not significantly predict turnover intention $(\beta=.03, p>.05)$. This implied that job stress was not a strong factor in turnover intention among workers in service occupations. Therefore, hypothesis 1 was not confirmed.

However, emotional labor significantly predicted turnover intention such that workers who reported emotional labor tended to form turnover intention $(\beta=.45, p<.01)$. Hypothesis 2 was confirmed by this result. Hypothesis 3 was also confirmed by the results in Table 2 . Emotional intelligence significantly predicted turnover intention in such a way that high emotional intelligence led to a decrease in turnover intention $(\beta=-.22, p<.01)$.

Job stress, emotional labor, and emotional intelligence jointly accounted for $61 \%$ variance in workers' turnover intention. The addition of these psychological variables to the model brought about a $37 \%$ change in turnover intention $\left(R^{2}=.61 ; \Delta R^{2}=.37 ; F(8,261)=2.53, p<.01\right)$.

Hypothesis 4 was tested with a t-independent test. The results are shown in Table 3.

Table 3: Summary of t- Test on Turnover Intention

\begin{tabular}{ccccccc}
\hline Service occupation & $\boldsymbol{N}$ & $\boldsymbol{M}$ & $\mathrm{SD}$ & $\boldsymbol{d f}$ & $\boldsymbol{t}$ & $\boldsymbol{p}$ \\
\hline Banking & 149 & 71.34 & 1.53 & 268 & 5.68 & $<.05$ \\
Health & 121 & 55.12 & 1.16 & & & \\
\hline
\end{tabular}

As indicated in Table 3, bank workers $(M=71.34 ; S D=1.532)$, compared with health workers $(M=55.12 ; S D=1.159)$, formed a significantly higher turnover intention $[t(268)=5.68, p<.05]$.

\section{Discussion}

This study investigated the extent to which job stress, emotional labor, and emotional intelligence were connected with turnover intention. Occupational differences in turnover intention among bank and health workers were also investigated.

As indicated in Table 2, job stress did not significantly predict the turnover intention among workers in service occupation. This result was not in consonance with the findings of previous studies (e.g. Adeyemo \& Afolabi, 2007; Oginni et al., 2013; Tuten \& Neidermeyer, 2004) that job stress was positively connected with turnover intention. This surprising result may be connected with the recent increase in unemployment rate, especially in Nigeria. Every worker, including bank and health workers, might have held on to their current job because new jobs were not easy to come by (Adebayo \& Ogunsina, 2011). Oginni et al. (2013) submitted that, in spite of the perceived negative conditions of their present job, dearth of alternative jobs could force workers to stay on a job while waiting for new job opportunities.

The result of the current study indicated that the more the workers in service occupations engaged in emotional labor the more they are likely form the intention to quit the organization. This finding corroborated with the finding of (Chau et al., 2009) who reported a significant effect of surface acting (emotional labor) on turnover intention. This result may be connected with the fact that workers in service occupations (e.g. banks and health) are usually obliged to express organizationally- or job-required emotions in order to create favorable atmospheres that promote good interpersonal transactions with customers or patients even if such emotions do not represent the workers' true feelings (Ehigie et al., 2012). When the displayed emotions consistently run contrary to their true feelings (Grandey, 2000; Morris \& Feldman, 1996), the workers may experience tension and depletion of energy and coping resources (Weiss \& Cropanzano, 1996), which might have resulted in turnover intention in order to escape the emotional incongruence generated by the job.

Emotional intelligence was connected with reduced turnover intention. This implied that workers who were emotionally intelligent reported low level of turnover intention. This result supported the positions of previous studies (e.g. Falkenburg \& Schyns, 2007; Lee \& Liu, 2007; Wong \& Law, 2002). It also corroborated the findings of Adeyemo et al. (2007) and Ajay (2009) that high level of emotional intelligence was related with low level of withdrawal cognition (thinking of quitting, desire to search for new a job, and willingness to quit a job). This was not surprising because individuals who are emotionally intelligent do not only possess the abilities to understand, regulate, and manage emotion in self and 
others (Goleman, 1995; Mayer, Salovey, \& Caruso, 2000; Salovey \& Mayer, 1990) but also use the emotional information for adaptive purposes (Bar-On, 2005; Furnham \& Christoforou 2007; Griffeth, 2000). This may explain why emotionally intelligent workers exhibited a reduced zeal to leave the job in spite of the perceived unfavorable working condition.

The present study also revealed that bank employees reported higher level of turnover intention than health workers. This may be because workers in the banking sector in Nigeria do not engage in work shift unlike those in the health sector. The recent bank recapitalization and consolidation policies in Nigeria have made banking job more tedious (Ogungbamila, 2010; Adejuwon \& Lawal, 2013) and less attractive. This new work circumstance in the banking sector might have triggered higher turnover intention in bank than health workers.

\section{Conclusion}

This study has shown that emotional labor and emotional intelligence are strong factors in turnover intention among workers in service occupations. Based on these findings, it was recommended that the level of emotional demands placed on employees should be reduced and their level of emotional intelligence should be enhanced.

In spite of the contributions of this study to literature, it is not without some limitations. The results should be generalized with caution because the sample size and spread did not adequately represent service occupations in Nigeria. Future studies, that include more service occupations, may lead to more beneficial results on the linkage between job stress and turnover intention.

\section{References}

AbdulRahman, S. M. M., Raza, N., \& Ismail, M. R. (2008). Measuring turnover intention: A study of IT professionals in Pakistan. International Review of Business Research Paper, 4(3), 45-55.

Adebayo, S. O. \& Ogunsina, S. O. (2011).Influence of supervisory behaviour and job stress on job satisfaction and turnover intention of police personnel in Ekiti State. Journal of Management and Strategy, 2(3), 13-20.

Adejuwon, A. G., \& Lawal, M. A. (2013). Perceived organizational target selling, self-efficacy, sexual harassment, and job involvement as predictors of psychological well-being of bank employees in Nigeria. Ife Psychologia, 21(1), 17-29.

Adeyemo, D. A., \& Afolabi, J. O. (2007). Influence of sexual harassment, occupational stress, emotional intelligence and job satisfaction on withdrawal cognition of female practitioners in Oyo State, Nigeria. Pakistan Journal of Social Sciences, 4(4), 639-646.

Ajay, K. J. (2009). Exploring the relative relevance of organizational citizenship behaviour and emotional intelligence. Journal of the Indian Academy, 35, 87-97.

Akinboye, J. O., \& Adeyemo, D. A. (2002). Coping with stress in life and workplace. Ibadan: Sterling-Horden Publishers.

Bakker, A. B., Demerouti, E., \& Schaufeli, W. B. (2003). Dual processes at work in a call centre: An application of the job demandsresources model. European Journal of Work and Organizational Psychology, 12(4), 393-417.

Balogun, A. G. \& Olowodunoye, S. A. (2012). Psychological factors as predictors of turnover intention among employees of postconsolidation banks in Nigeria. European Scientific Journal, 8(20), 81-95.

Bar-On, R. (2005). The impact of emotional intelligence on subjective well-being. Perspective in Education, 23(2), 41-62.

Brotheridge, C. M., \& Lee, R. T. (2003). Development and validation of the Emotional Labor Scale. Journal of Occupational and Organizational Psychology, 76(3), 365-379.

Carmeli, A. (2003). The relationship between emotional intelligence and work attitudes, behaviour and outcomes. Journal of Management Psychology, 18, 788-813.

Chau, S. L., Dahling, J. J., Levy, P. E., \& Diefendorff, M. (2009). A predictive study of emotional labor and turnover. Journal of Organizational Behaviour, 30, 1151-1163.

Chu K. H. L., (2002). The effects of emotional labor on employee work outcomes. Unpublished Dissertation, Virginia Polytechnic Institute and State University.

Ehigie, B. O. (2002). Identification of stressors in the banking industry. Journal of School of Management and Business Studies, 1(1), 1929.

Ehigie, B. O., Oguntuase, R. O., \& Ibode, F. O., \& Ehigie, R. I. (2012). Personality factors and emotional intelligence as predictors of Frontline Hotel employees' emotional labor. Global Advanced Research Journal of Management and Business Studies, 1(9), 327-338.

Falkenburg, K., \& Schyns, B. (2007). Work satisfaction, organizational commitment and withdrawal behaviours. New Management Research, 30,708-723.

Furnham, A., \& Christoforou, I. (2007). Personality traits, emotional intelligence, and multiple happiness. North American Journal of Psychology, 9(3), 439-462.

Galletta, M., Portoghese, I., \& Battistelli, A. B. (2011). Intrinsic motivation, job autonomy and turnover intention in Italian healthcare: The mediating role of affective commitment. Journal of Management Research, 3(2), 1-19.

Goleman, D. (1995). Emotional intelligence: Why it can matter more than IQ. New York: Bantam Books.

Goleman, D. (1998). Working with emotional intelligence. London: Bloomsbury Publishing,. 
Grandey, A. (2000). Emotion regulation in the workplace: A new way to conceptualize emotional labor. Journal of Occupational Health psychology, 5(1), 95-110.

Griffeth, R. W., Hom, P. W., \& Gaertner, S. (2000). A meta-analysis of antecedent and correlates of employee turnover: Update, moderator test, and research implications for the next millennium. Journal of Management, 26, 463-488.

Hochschild, A. R. (1983). The managed heart: Commercialization of human feelings. Berkley, CA: University of California Press.

Karasek, R. (1979). Job demands, job decision latitude, and mental strain: Implications for job redesign. Administrative Science Quarterly, 24, 285-307.

Lee, H., \& Liu, C. (2007). An examination of factors affecting repatriates' turnover intention. International Journal of Manpower, 2, 122134.

Miller, Y. (2010). Labor turnover and its impact on customer service and success of restaurants in London. Retrieved from http://www.articleblast.com on the July $6^{\text {th }}, 2010$.

Mobley, W. H., Horner, S. O., \& Hollingsworth, A. T. (1978). An evaluation of precursors of hospital employees' turnover. Journal of Applied psychology, 63, 408-414.

Morris J. A. \& Feldman, D. C. (1996). The dimensions, antecedents, and consequences of emotional labor. Academy of Management Review, 21(4), 986-1010.

Mustapha, A. \& Mourad, M. (2007). Employee turnover and retention strategies: Evidence from Saudi companies. International Review of Business Research Papers, 3(3), 1-16.

Ngo, H. Y., Sharon, F., \& Raymond, L. (2005). Work role stressors and turnover intentions: A study of professional clergy in Hong Kong. International Journal of Human Resource Management, 16(11), 2133-2146.

Oginni, B. O., Afolabi, G., \& Erigbe, P. (2013). The place of job stress in labor turnover of the banking sector in the Nigerian economy. International Journal of Business and Management Invention, 2(1), 93-99.

Ogungbamila, B. (2010). Effect of felt obligation on occupational burnout among employees of post-consolidation banks in Nigeria. Ife Psychologia, 18(2), 137-149.

Ogungbamila, B. (2011). Perception of organizational injustice, negative emotions, and emotional intelligence as predictors of workplace reactivity among local government employees in southwest Nigeria. Unpublished PhD Thesis, University of Ibadan.

Ogungbamila, B. (2013). Occupational burnout among employees in some service occupations in Nigeria: Are health workers different? Psychological Thought, 6(1), 153-165.

Ojedokun, A. O. (2008). Perceived job insecurity, job satisfaction and intention to quit. African Journal for the Psychological Study of Social Issues, 11(2), 204-220.

Owolabi, A. B. (2012). Effect of organizational justice and organizational environment on turn-over intention of health workers in Ekiti State, Nigeria. Research in World Economy, 3(1), 28-34.

Oyetola, S. O. (2013). Influence of job satisfaction on turnover intentions of library personnel in selected universities in South West Nigeria. Retrieved from http://digitalcommons.unl.edu/libphilprac/914 on the 21 $1^{\text {st }}$ May, 2013.

Pascal, P. (2011). Stressful work, citizenship behaviour and intention to leave the organization in a high turnover environment: examining the mediating role of job satisfaction. Journal of Management Research, 3(1), 1-14.

Price, J. I. (2001). Reflections on the determinants of voluntary turnover. International Journal of Manpower, 22(7), 624-660.

Salami, S. O. (2008). Demographic and psychological factors predicting organizational commitment among industrial workers. Anthropologist, 10(1), 31-38.

Salovey, P. \& Mayer, J. D. (1990). Emotional intelligence. Imagination, Cognition and Personality, 9(3), 185-211.

Salovey, P., Mayer, J. D., Goldman, S. L., Turvey, C., \& Palfai, T. P. (1995). Emotional attention, clarity, and repair: Exploring emotional intelligence using the Trait Meta Mood Scale. In J. W. Pennebaker (Ed.), Emotion, disclosure, and health (pp. 12-154). Washington DC: American Psychological Association.

Theorell, T. (1988). The demands-control-support model for studying health in relation to the work environment: an interactive model. In K. Orth-Gomer \& N. Schnelderman (Eds.), Behavioural medicine approaches to cardiovascular disease (pp.69-85). Mahwah, NJ: Erlbaum Associates.

Tuten, T. L., \& Neidermeyer, P. E. (2004). Performance, satisfaction and turnover in call center: The effects of stress and optimism. Journal of Business Research, 57, 26-34

Wagner, C. M. (2010). Predicting nursing turnover with catastrophe theory. Journal of Advanced Nursing, 66, 2071-2084.

Weiss, H. M., \& Cropanzano, R. (1996). Affective events theory: A theoretical discussion of the structure, causes and consequences of affective experiences at work. Research in Organizational Behavior, 18, 1-74.

Wong, C., \& Law, K. (2002). The effects of leader and follower emotional intelligence on performance and attitude: An exploratory study. The Leadership Quarterly, 13, 243-274. 
